Grega Strban, Professor, Dr.

University of Ljubljana, Slovenia

\title{
THE RIGHT TO SOCIAL SECURITY: FROM STATE TO EU RESPONSIBILITY?
}

\begin{abstract}
Summary
The right to social security is a fundamental human right, emphasising solidarity and equality among the members of society. Historically, responsibility has shifted from family to State or social solidarity. Social relations are changing faster than ever before. We are facing new forms of families and organisation of work. Within the EU, mobility is promoted, also with regard to cross-border healthcare. Can the existing EU and national social security laws cope with all the changes, or would more competence of the EU be required in order to preserve the right to social security?
\end{abstract}

Keywords: social security, coordination, cross-border healthcare, family benefits, nonstandard workers, equal treatment

\section{Introduction}

The right to social security is one of the fundamental human rights, often not in the forefront of the human rights law, which is predominately guided by the European Convention on Human Rights. Nevertheless, especially during the quite recent times of crises, the importance of the right to social security has been (re)emphasised.

Historically, family solidarity has been expressed among family members of, as a rule, larger rural families. ${ }^{1}$ With industrialisation, the structure of the family has changed and workers were left without the support extended by larger families, fraternities and mutual insurance companies. In order to restrict workers' movement and remain in power, German Chancellor and Prussian Prime Minister Otto von Bismarck advocated social insurance, financed by workers and their employers. The first State-organised social security system was thereby established. ${ }^{2}$

Social security is first and foremost regulated by national law, which takes into account various historically conditioned and rather distinctive structural

1 The Slovenian Constitutional Court also took solidarity between family members as a basic starting point. It argued that when the legislator decides to completely replace the family solidarity with social solidarity, it has to ensure such solidarity (not merely abolish the maintenance duty for disabled children after reaching certain age). Judgment of Slovenian Constitutional Court of 13 December 2007 in case No. U-I-11/07. Available at: http://odlocitve.us-rs.si/documents/b9/45/u-i-11-074. pdf [last viewed December 6, 2019].

2 More Köhler P. A., Zacher H. F. Ein Jahrhundert Sozialversicherung in der Bundesrepublik Deutschland, Frankreich, Großbritannien, Österreich und der Schweiz [Hundred years of social insurance in the Federal Republic of Germany, France, Great Britain, Austria and Switzerland]. Berlin: Duncker \& Humblot, 1981. 
(e.g. educational, living and working conditions) and cultural elements (e.g. powers of trade unions or civil movements), policy preferences (which may emphasise more individual responsibility or more solidarity), and even ideologies in every State. This is the reason why national social security systems have not developed in a more uniform way. ${ }^{3}$

However, societal relations are changing and stemming from the rule of law is the duty of the legislature to follow this development with its normative action. Moreover, family structures, forms of work organisation and patterns of mobility have changed. Single-parent and same-sex families are nothing new anymore. We have concepts of father-plus (instead of stepfather) and co-mothership in some Member States. Work could be organised via electronic platforms, be of short duration, last for a limited time period, even on-call, and self-employed persons may be economically dependent or actually perform work as workers. Moreover, patterns of movement have changed from longer residence to shorter term stays in another Member State. All these factors influence the shaping of social security systems.

Therefore, the question is, whether the right to social security could still be guaranteed by the Member States alone, based on the principle of territoriality, or does it call for a greater involvement of the European Union (EU)? It should enable and even promote mobility within the Union. Hence, the research question of the present paper is to what extent the responsibility of providing social security is and should be divided between the Member States and the EU as a supranational structure. Could it be argued that, in order to safeguard national social security systems under the more dynamic development of societal relations, more EU competencies in social security are required?

\section{The right to social security}

The right to social security is firmly rooted in international, European and national constitutional law. It is built upon the principle of solidarity among the various groups in a given society.

\subsection{Fundamental social right}

Human rights are at the core of civilised societies. They are not only limiting the powers of the State, but are the purpose and guidance of the State's (also normative) action. The culture of human rights in the democratic society governed by the rule of $\mathrm{law}^{4}$ is emphasised for at least 70 years, since the adoption of

3 For an overview, see www.missoc.org [last viewed November 02, 2019].

4 Furthermore, democracy, rule of law and human rights are firmly emphasised by the Council of Europe. 
the Universal Declaration of Human Rights (UDHR) ${ }^{5}$, which reflects the human kind as aspiring to live in peace by respecting, promoting and protecting all human rights, including social rights.

Foundation of social human rights is the presumption of principal equality of all people. It is based on the conviction that optimisation of individual interest does not necessarily guarantee the highest social interest. Hence, next to civil and political rights, social rights are equally important. The right to social security is indispensable for connecting people within a certain (national or even supranational) society. ${ }^{6}$ It should guarantee every individual and society as such existence and more or less free development.

The right to social security is well established in international law as one of the fundamental human rights. It is regulated not only in the UDHR, ${ }^{7}$ but also in the International Covenant on Economic, Social and Cultural Rights (ICESCR $)^{8}$ and the Convention on the Rights of the Child (CRC). ${ }^{9}$ At the European level, the right to social security is enshrined in the (initial and revised) European Social Charter (ESC $)^{10}$ of the Council of Europe and the Charter of Fundamental Rights of the EU (CFR-EU). ${ }^{11}$ The ESC formulates the right to social security by obliging the Contracting Parties, i.e. the States, to ensure it.

The ILO Convention 102 (1952) was the first and remains one of the most important international instruments to define the substance of the international human right to social security. ${ }^{12}$ It lists nine social risks and limits its scope to the 'traditional' social security branches and described categories. At the time, standard beneficiary, for whom the benefits should suffice, was a man with his wife and two children. Social security systems have been built around such perception of a single-breadwinner model, which today, of course, has become outdated.

5 Very recently another important declaration has been adopted by the UN General Assembly, i.e. Declaration on Universal Health Coverage. Available at: https://www.un.org/pga/73/wp-content/ uploads/sites/53/2019/07/FINAL-draft-UHC-Political-Declaration.pdf [last viewed November 2, 2019].

6 It could hardly be agreed that 'there is no such thing as society' as advocated in 1987 by former UK Prime Minister Margaret Thatcher. Available at: https://www.margaretthatcher.org/document/ 106689 [last viewed November 2, 2019].

Articles 22 and 25, UDHR.

8 Article 9, ICESCR.

9 Article 26, CRC.

10 Article 12 of the (initial and revised) ESC.

11 Article 34, CFR-EU, OJ C 202, 7.6.2016.

12 Although it neither enshrines the right to social security nor defines social security as such. 
Nevertheless, ILO Convention 102 has been an important source of inspiration for other international legal instruments. ${ }^{13}$ Moreover, the right to social security is also enshrined in many national constitutions, including the Slovenian and the Latvian constitutions. ${ }^{14}$ As such, it cannot be regulated as a very precise and concrete legal rule. It is one of the basic values and guidance for all legal subjects in a society. It has to be noticed that there might be no direct correlation between the constitutional provisions and concrete rights stemming from the social security system. Hence, the right to social security has to be determined, first and foremost, by the national legislature, by regulating individual social security rights of insured persons (and other beneficiaries). By doing so, it also draws a line between public and private responsibility for providing income security when one of the social risks or a specific situation of need occurs.

In more general terms, social security can be described as a public system of income protection in case of its loss or important reduction (e.g. due to old age, invalidity, decease, accident at work or occupational disease, sickness, maternity or unemployment) or in case of increased costs (e.g. for healthcare, raising of children or reliance/dependency on long-term care), organised through a process of (broader or narrower) social solidarity. ${ }^{15}$ The latter could be vertical, horizontal or intergenerational solidarity. ${ }^{16}$

\subsection{Solidarity as a cornerstone of social security}

Solidarity is the most important characteristic of any social security system. It is differentia specifica between social and private insurance (where certain reciprocity between insured persons may exist, but solidarity is as a rule absent). Its slogan of liberty, equality and brotherhood (Fr. liberté, égalité, fraternité) was developed in the times of the French revolution (1789). These values were also incorporated in the UDHR. Its first Article states that all human beings are born free and equal in dignity and rights. They are endowed with reason and conscience and should act

13 The initial ESC sets as satisfactory standard of social security the standard required for the ratification of the ILO Convention No. 102. The latter was used as a model for the initial Code of Social Security, which is a standard of the satisfactory level of social security for the revised ESC. Also, the Regulation (EC) 884/2004 on coordination of social security systems enumerates in its material scope the same branches of social security as found in the ILO Convention No. 102. Moreover, the CFR-EU does not mention only the traditional risks, but adds a "new" one, i.e. "dependency" (reliance on long-term care).

14 Article 50 of the Slovenian Constitution and Article 109 of the Latvian Constitution. Other articles may be of importance, since they relate not only to healthcare, human dignity and rights of specific groups of people (e.g. persons with disabilities), but also the nature of the state, social state or socially responsible state, respectively.

15 Pieters D. Social Security: An Introduction to the Basic Principles, $2^{\text {nd }}$ edition, Alphen aan den Rijn: Kluwer Law International, 2006, p. 2.

16 More on solidarity: Strban G. Constitutional protection of the right to social security in Slovenia. In: Egorov A., Wujczyk M. (eds.), The Right to Social Security in the Constitutions of the World: Broadening the Moral and Legal Space for Social Justice. ILO Global Study, Vol. 1: Europe. Geneva; ILO, 2016, p. 245. 
towards one another in a spirit of brotherhood. In the times of gender equality, it would be only equitable to add also in the spirit of sisterhood, or maybe a more general term of solidarity could be used instead.

Solidarity has gained importance also in the EU law, where it is expressly mentioned. Treaty on European Union, signed in Maastricht on 07.02.1992 [in the wording of 07.06.2016], emphasises the values, which are common to all Member States ${ }^{17}$ in a society characterised not only by pluralism, non-discrimination, tolerance, justice, equality between women and men, but also solidarity. Among distinctive forms of solidarity, the solidarity between generations is accentuated and should be promoted. ${ }^{18}$

Moreover, the CFR-EU, which has the same legal value as the Treaties, explicitly mentions solidarity as an indivisible and universal value of the Union. ${ }^{19}$ In a special chapter, titled "Solidarity", the Charter defines the rights to social security, social assistance and health care. ${ }^{20}$ Although the Charter does not introduce new competencies of the $\mathrm{EU},{ }^{21}$ it is an important guidance in interpretation of the EU law, also by the Court of Justice of the EU (CJEU). ${ }^{22}$

Solidarity in a more specific sense also plays a role when it comes to the influence of basic economic freedoms and the EU competition law on national social security systems. According to the CJEU, systems based on solidarity (or carriers of such systems) cannot be qualified as undertakings and are exempted from the application of competition law. ${ }^{23}$

Solidarity constitutes a core principle of European social security and unites European national constitutions on the basis of their shared values. It is laid down as an express legal norm in many constitutions, including the Latvian one. ${ }^{24}$ In Slovenia, the Constitutional Court on several occasions has mentioned solidarity

17 The values are human dignity, freedom, democracy, equality, the rule of law and human rights. Article 2 Treaty on EU, OJ C 202, 7.6.2016 (consolidated version).

18 Article 3 of the Treaty on EU.

19 Second paragraph of the preamble, CFR-EU.

20 Title IV, Articles 34 and 35, CFR-EU.

${ }^{21}$ Article 6 Treaty on EU and Article 51 CFR-EU.

22 E.g. CJEU judgments of 8 March 2011 in case No. C-34/09 Zambrano, of 24 April 2012 in case No. C-571/10 Kamberaj. It might also play a role in the pending Latvian case No. C-243/19 Veselibas ministrija.

23 More in CJEU judgments of 17 February 1993 in joined cases No. C-159/91 and C-160/91 Poucet et Pistre, but also in some later cases like CJEU judgments of 3 March 2011 in case No. C-437/09 AG2R Prévoyanc, of 5 March 2009, in case NO. C-350/07 Kattner Stahlbau, or in the field of social security of migrant workers CJEU judgment of 14 October 2010 in case No. C-345/09 van Delft et al.

24 See the preamble of the Latvian Constitution. For instance, in Austria, Italy, Spain, France, Belgium and the Netherlands, the solidarity principle is at any rate invoked to establish and legitimate the existence of social insurance. Becker U. Solidarity, Financing and Personal Coverage. The Japanese Journal of Social Security Policy, No. 1, 2007, p. 1. The Slovenian Constitutional Court has also emphasized solidarity as a core of the social state principle, enshrined in Article 2 of the Slovenian Constitution. 
between persons with higher earnings and those with lower income (the so-called vertical solidarity), as well as intergenerational solidarity. ${ }^{25}$

The right to social security is in many Member States (mainly of continental Europe) provided by social insurance schemes. They have to be mandatory in order to establish relations between persons who present a higher (social) risk with those who present a lower (social) risk. It may sound as a paradox, but due to such coercion (and mandatory pooling of risks), both groups may enjoy more freedom. An individual would be willing to engage in more risky activities, if he/she would be confident that there is a legally regulated social security system guaranteeing certain rights in case of sicknesses or injury, unemployment, old-age, reliance on long-term care, invalidity or decease.

\section{Sharing of competencies in social security}

Competencies in the field of social security are shared between the Member States and the EU. Member States are exclusively competent to shape the substance of their social security systems, i.e. its personal and material scope, as well as enforcement procedures. Hence, considerable differences between social security systems within the EU remain present. ${ }^{26}$

When the Member States fall short of achieving the goal themselves, e.g. the goal of freedom of movement in the EU, or when a certain fundamental legal principle has to be ensured, the EU steps in. Hence, the EU holds certain, even if limited, competencies in harmonising the substance of social security systems. They concern equal treatment of women and men, legally non-binding cooperation between the Member States in a form of Open Method of Coordination (OMC) and a recent European Pillar of Social Rights (EPSR), encompassing Social protection and inclusion.27

\subsection{Freedom of movement within the EU}

In order to guarantee free movement of workers (Article 45 TFEU $)^{28}$ and Union citizens in General (Article 21 TFEU), social security systems have to be coordinated, i.e., legally and administratively linked. ${ }^{29}$ Some of the coordination

25 See Strban G. Constitutional protection of the right to social security in Slovenia, 2016, p. 247.

26 The continental Member States mainly realise the right to social security by way of contributory financed social insurances. Some northern, as well as some southern Member States implement or combine it with tax-financed, residence-based national protection schemes. See www.missoc.org [last viewed November 2, 2019].

27 Commission recommendation on the European Pillar of Social Rights, C(2017) 2600 final, Brussels, 26.04.2017.

28 Treaty of the Functioning of the European Union (TFEU), OJ C 202, 07.06.2016 (consolidated version).

29 Article 48, TFEU. 
techniques are explicitly mentioned by Article 48 TFEU, i.e. aggregation of all relevant insurance, employment or residence periods and export of social security benefits to another Member State.

Moreover, self-employed "workers" have been squeezed into Article 48 TFEU in order to gain explicit legal basis for coordinating their social security. Although, other provisions of TFEU primarily apply to self-employed persons, such as freedom of establishment and freedom of providing services. ${ }^{30}$

The measures in the field of social security, which are necessary to provide freedom of movement of (economically active) persons have to be passed in accordance with the ordinary legislative procedure and no longer unanimously. ${ }^{31}$

However, a so-called "alarm procedure" or "brake procedure" has been installed. If the Commission proposal were to affect important aspects of its social security system (including its scope, cost or financial structure) or impact the financial balance of that system, the Member State may refer the matter to the European Council. The ordinary legislative procedure is suspended, and the European Council may accept or reject the proposal. ${ }^{32}$

Nevertheless, the European Council, as a rule, adopts its decisions unanimously (except where the Treaties provide otherwise). Hence, the Member State referring the matter to the European Council may still block the adoption of the proposal in the Council. Moreover, if no decision is taken in four months, it is deemed that the originally proposed act has not been adopted. The right of Member States to a veto has not been completely abolished, but merely modified.

In addition, for the economically non-active persons, a second legal basis, i.e., Article 352 TFEU remains applicable, according to which unanimity is always required. All this is an expression of reluctance of the Member States to transfer the competence in the social security field to the EU and to limit the influence of the EU law to national social security systems.

\subsection{Coordination with a regulation}

It is correct that EU law does not unify national social security systems. However, paradoxically, their coordination is achieved with a Regulation, which is a unifying measure. It is generally applicable, binding in its entirety and directly applicable in all Member States ${ }^{33}$. The attribute of direct applicability is linked to the doctrine of supremacy. In principle, it is not open to Member States to interfere with the direct application of a regulation in the national legal order. Nevertheless, social security systems are not unified, at least not in their substance. Rather, the part of formal

\footnotetext{
30 Articles 49 and 56, TFEU.

31 After coming into force of the Lisbon Treaty in December 2009 (OJ C 306, 17.12.2007). Articles 48, 294 TFEU.

32 Jorens Y., Van Overmeiren F. General Principles of Coordination in Regulation 883/2004, European Journal of Social Security (EJSS), 2009, No. 1-2, p. 55.

33 Article 288, TFEU.
} 
social security law, governing the application of the substantive social security law in cross-border situations, is unified among all Member States. Positive and negative conflicts of national social security laws are prevented.

Historically, the text on coordinating social security systems of the six founding Member States of the $\mathrm{EU}^{34}$ was agreed upon in the form of an international convention. However, it was decided to avoid the time-consuming procedure of ratification ${ }^{35}$ and the already agreed rules were passed in the form of a regulation. In fact, it was the third regulation ever adopted by the EU, i.e., Regulation (EEC) No. $3 / 58$ concerning the social security of migrant workers. ${ }^{36}$ It was the first real legal instrument of the EU. ${ }^{37}$ The Regulation (EEC) No. 4/58 was the implementing Regulation, mainly containing rules of behaviour of the institution responsible for social security coordination..$^{38}$

Choosing a regulation over the traditional international convention has important implications. It gives the CJEU the possibility to interpret the secondary legislation and establish its conformity with the Treaties, or apply the Treaties directly to the situations under the material scope of EU law.

However, the patterns of migration are changing and the states with distinctive social security systems (no longer based on economic activity, but rather on residence in the country) have joined the Union. Therefore, Regulation (EEC) No. 1408/71 and its implementing Regulation (EEC) No. 574/72 were introduced. With many modifications, some to codify, some to oppose the judgments of the CJEU, they have become a very complex piece of Union legislation.

The process of modernisation and simplification of social security coordination law resulted in the Regulation (EC) No. 883/2004. It was passed only a couple of days before the largest enlargement of the EU so far. ${ }^{39}$ The 10 states (among them Latvia and Slovenia) joined the EU on the first of May 2004 and the unanimity of $25 \mathrm{Member}$ States would be required. The lengthy procedure of obtaining unanimity is shown in passing the implementing Regulation (EC) No. 987/2009 ${ }^{40}$, five years later. Both Coordination Regulations are applied since May 2010. It could be argued, that the more diverse the social security systems of the growing number of Member States have become, the more complex coordination regime is required. ${ }^{41}$

34 Founding Member States were Belgium, France, Germany, Italy, Luxembourg and the Netherlands.

35 More in: Strban G. Social rights of migrants in the European Union. In: Regional aspects of integration: European Union and Eurasian space. Davletgildeev R. Sh. (ed.), Moscow: Statut, 2019, p. 73.

36 OJ L 30, 16.12.1958.

37 Regulations No. 1 and 2 dealt with the use of languages and the form of the laisser passer to the Members of the European Parliament, respectively.

38 Both Regulations became applicable as of January 1959.

39 OJ L 166, 30.4.2004. The latest proposal for the revision of Coordination Regulations was presented in December 2016. Strasbourg, 13.12.2016, COM(2016) 815 final.

40 OJ L 284, 30.10.2009.

${ }^{41}$ The same applies vice versa. The more similar the national social security systems are, the less complicated their coordination is. 
Some principles of social security coordination law can be deducted already from primary law (the Treaties), ${ }^{42}$ while others - from the secondary law, most notably, from the Coordination Regulations. ${ }^{43}$ These principles are equal treatment of Union citizens, unity of applicable legislation, protection of the rights in course of acquisition (with aggregating all relevant periods), protection of acquired rights (with export of benefits) and good administrative cooperation (e.g. by exchanging first electronic documents between Austria and Slovenia in 2019). ${ }^{44}$

\section{Specific issues of coordinating national social security systems}

Modified social relations present a challenge not only for national social security systems, but also for the EU social security coordination law. Examples might encompass cross-border healthcare, export of family benefits and coordination of social security for non-standard workers and self-employed.

\subsection{Cross-border healthcare}

Revived interest in cross-border healthcare has been triggered by the adoption of the Directive 2011/24/EU, ${ }^{45}$ although it has been already enabled by the Coordination Regulations and certain provisions of national law (not to mention bilateral and multilateral social security agreements). It may sound as another paradox that a user of national legal norms might be more familiar with a Directive, which has to be transposed into national law, rather than a Regulation, which has to be read alongside it (although it is applicable in its entirety in all Member States).

Nevertheless, the Directive 2011/24/EU codified the CJEU case law and established a parallel system of social security coordination. It is not based on linking national public, social security systems in order to provide healthcare to insured persons, which cannot be provided in a home Member State in due time, but promotes free movement of (medical) goods and (health) services in the internal market. Prior authorisation according to Coordination Regulations is an obstacle to such free movement and may be justified only in exceptional cases (of hospital

42 Articles 18, 21, 45 and 48, TFEU.

43 More in: Strban G. Social rights of migrants in the European Union. In: Regional aspects of integration: European Union and Eurasian space. Davletgildeev R. Sh. (ed.), Moscow: Statut, 2019, p. 75 .

44 Available at: https://www.zzzs.si/ZZZS/info/gradiva.nsf/0/3517d834858ff3cac12584410032c e88/\$FILE/PR_ESSI\%20izmenjava\%20podatkov\%20z\%20Avstrijo_24.7.2019.pdf [last viewed November 2, 2019].

45 Directive 2011/24/EU on the application of patients' rights in cross-border healthcare, OJ L 88, 4.4.2011. 
treatment or use of highly specialised and cost-intensive medical infrastructure or medical equipment). ${ }^{46}$

The situation might get complicated, when the same healthcare provider offers medical services for public and private patients. A tendency might arise to treat cross-border patients as private patients, with no waiting lists in a nicer setting and with kinder personnel due to direct payment. However, direct payment (of as a rule higher private prices) may be afforded only by a limited number of betteroff private patients. Reimbursement of healthcare costs (according to the prices of the competent, home Member State) might be requested later on, but not in all situations. ${ }^{47}$ Steering the patients towards private provision of healthcare is, as a rule, not allowed. However, cross-border patient lacks all specific information on healthcare provision in the Member State of treatment in order to make an informed and truly free choice.

Moreover, an insured person may be treated by a purely private physician (outside of public healthcare network) in another Member State, which might not be possible in the home Member State, at least not at the account of the public healthcare system (social health insurance or national health service). Is it a kind of reverse discrimination ${ }^{48}$ and is it legally admissible? From the aspect of the EU law, a moving person should not be in a worse legal position than a non-moving person, but he or she might be in a better one. ${ }^{49}$ Hence, it is the question of choosing a better law (national or EU law), but, the choice could only be made when crossing the border. Nevertheless, should not the highest attainable standard of health ${ }^{50}$ be provided to all EU citizens, moving or not within the Union? The CJEU has already recognised the rights based on EU citizenship alone, without any (direct) movement within the Union. ${ }^{51}$ Or should the national law be modified in order to allow access

46 Article 8, Directive 2011/24/EU. More in: Strban G. Patient mobility in the European Union: between social security coordination and free movement of services, ERA Forum, No. 3, 2013, p. 392. Carrascosa Bermejo D. Cross-border healthcare in the EU: Interaction between Directive 2011/24/EU and the Regulations on social security coordination, ERA Forum, No. 3, 2014, p. 366.

47 E.g. if prior authorisation is required, but not issued under the Directive 2011/24/EU.

48 A so-called reverse discrimination might occur when an EU citizen finds him- or herself in a purely internal legal situation of a certain Member State and cannot rely upon the EU law (on the free movement of services) to obtain a certain benefit. Only national law could be invoked, which is less favourable than EU law. Verschueren H. Reverse Discrimination: An Unsolvable Problem. In: Minderhoud P., Trimikliniotis N. (eds.), Rethinking the free movement of workers: the European challenges ahead, Nijmegen: Wolf Legal Publishers, 2009, p. 99.

49 So-called Petroni principle (after CJEU judgment of 21 October 1975 in case No. C-24/75 Petroni) or principle of favourability.

50 Article 12 ICESCR and Point 11, Part I (initial and revised) ESC.

51 CJEU judgment of 8 March 2011 in case No. C-34/09 Zambrano. CJEU judgment of 1 April 2008 in case No. C-212/06 Government of the French Community and the Walloon Government v. The Flemish Government. 
to purely private physicians in the Member State of affiliation (possibly with lower reimbursement) $?^{52}$

\subsection{Family benefits}

There are many issues related to coordination of the entire plethora of family benefits, existing in each Member State. ${ }^{53}$ The EU social security coordination law employs a rather broad notion of family benefits. It encompasses all benefits in kind and in cash intended to meet family expenses, excluding advances of maintenance payments and special childbirth and adoption allowances (listed in Annex I to the Coordination Regulation). ${ }^{54}$

Coordination of such variety of family benefits has become a challenge. Additionally, CJEU is trying to find the best possible solution for a moving person, e.g. by designating as a competent Member State outside of the Coordination Regulations rules ${ }^{55}$ or by establishing family benefits of distinctive kind and hence providing more family benefits in their full amount. ${ }^{56}$

Moreover, Member States are trying to circumvent the Coordination Regulations by adjusting (indexing) the benefits according to the living costs in the Member State of children's residence. Austria, seems to be the first one to act upon such idea. ${ }^{57}$ Since the beginning of 2019, family benefits are actually adjusted. ${ }^{58}$ Adjustment goes both ways. Nevertheless, many more children of cross-border workers in Austria live in lower income Member States and Austria is reducing its expenditure for family benefits. However, the compatibility with the EU law is questioned, since CJEU already established inadmissibility due to unequal treatment of workers in its previous case law. ${ }^{59}$

52 E.g., as in the case of Austria, reimbursing 80 percent of public price to all insured persons visiting a physician outside of public healthcare (in Austria or any other Member State). If many insured persons opt for it, public system might remain only for poor persons. Systems for poor may become poor systems as such.

53 More Strban G. Family benefits in the EU - is it still possible to coordinate them? Maastricht Journal of European and Comparative Law (MJ), No. 5, 2016, p. 775.

54 Article 1(z) of Regulation (EC) 883/2004.

55 CJEU judgment of 20 May 2008 in case No. C-352/06 Bosmann. CJEU judgment of 12 June 2012 in joined cases No. C-611/10 and C-612/10 Hudziński and Wawrzyniak.

56 CJEU judgment of 8 May 2014 in case No. C-347/12 Wiering.

57 The idea is supported also by Denmark, Germany, the Netherlands, and the UK. See also the Conclusions of the European Council meeting on 18 and 19 February 2016, Brussels, 19 February 2016, EUCO 1/16 (special arrangements never came into force, due to the referendum "Leave" vote in the UK on 23 June 2016).

58 Familienlastenausgleichsgesetz and Einkommensteuergesetz, both BGBl. I No. 83/2018.

59 CJEU judgment of 15 January 1986 in case No. C-41/84 Pinna. CJEU judgment of 7 November 2002 in case No. C-333/00 Maaheimo. See also E. Felten, Export von Sozialleistungen, Soziale Sicherheit Online, March 2017. Available at: www.hauptverband.at [last viewed November 2, 2019]. 


\subsection{Non-standard workers}

Social security systems were primarily developed for a worker with a permanent, full-time employment contract for an indefinite period of time, upon which standard social security is built. Non-standard forms of employment and new forms of self-employment are deviations from the standard, i.e. temporary or short-term contracts, part-time work, employment relationships between more than two parties, casual work, including on-demand work and intermittent contracts, platform work temporary agency work, domestic work, voucher-based work, telework, traineeship and student work, self-employment, especially involuntary, bogus, dependent, new and part-time self-employment, or other country-specific non-standard contracts (mini-jobs, civil law contract, etc.).

Such new forms of organising work present not only challenges for national social security systems, which try to assimilate non-standard workers with workers or self-employed persons, but also for the EU social security coordination law. It is no longer clear, how such work might be classified in order to determine the legislation of which Member State is applicable. Marginal work is not taken into account only when a person is simultaneously employed in two or more Member States, but if in one he or she is self-employed, the closest link seems to be with (marginal) employment. Moreover, could marginal employment in more Member States still be considered as marginal? What if the competent Member State (according to the lex loci laboris rule) provides limited or no protection? ${ }^{60}$ Should it still be applied or should another closest link to such non-standard worker be established? For instance, self-employed may only voluntarily be covered by certain schemes, and voluntary insurance is not coordinated, or country or work might not consider marginal work (mini jobs) for social security purposes. Also, the minimum of one year of pension insurance in a Member State in order to aggregate such period might be questioned with regard to shorter stays in another Member State. ${ }^{61}$

\section{Equal treatment of women and men}

The Treaty of Rome provided legal bases not only for the coordination of national social security systems, but also for gender equality. It is harmonisation of the legal standard of equal treatment of women and men. It could be argued that social security coordination and gender equality represent the two pillars of the EU social security law. The distinction is that for application of the latter no cross-border

60 CJEU judgment of 23 April 2015 in case No. C-382/13 Franzen et al. CJEU judgment of 19 September 2019 in joined cases No. C-95/18 and C-96/18 van den Berg and Giesen.

${ }^{61}$ More in Strban, G. (coord.), Carrascosa Bermejo, D., Schoukens, P., Vukorepa, I. Social security coordination and non-standard forms of employment and self-employment: Interrelation, challenges and prospects, MoveS Analytical report 2018, not yet published. 
movement is required. Both the TEU and the TFEU prohibit differentiation on the basis of gender as a matter of principle. ${ }^{62}$

The acceptance of the social and economic importance of ensuring equality is reflected also in the CFR-EU. It contains general anti-discrimination provision, where the negative aspect is stressed, i.e. any discrimination based on sex is prohibited. Moreover, special provision is emphasising a positive aspect, i.e. ensuring equality between women and men and advocating positive measures providing specific advantages in favour of the underrepresented sex. Both provisions are general enough to cover also gender differences in social security. ${ }^{63}$

More direct legal influence is provided by the non-discrimination directives. The only directive still in force from the initial 1970s "package" is Directive 79/7/EEC. ${ }^{64}$ This is no coincidence, since the Member States are still rather reluctant to transfer their competencies in social security to the EU. ${ }^{65}$ Moreover, based on the single breadwinner model, the gender discrimination may still exist, e.g. when recalculating part-time work to full time equivalent, which may cause indirect discrimination of women. ${ }^{66}$

\section{Conclusions}

Social security is and even has to be one of the most rapidly changing areas of law. When it aspires to fulfilling its basic task and providing security to the people, it has to be adapted to continuously changing society. The principle of adjustment of the law to social relations is one of the principles of the state governed by the rule of law. ${ }^{67}$

Moreover, the relations in the European society also have changed. It is characterised by more dynamic and shorter movement patterns, new forms of families and cross-border economic activities. New legal paths of cross-border healthcare maintain an evergreen discussion on delineating between public and private income security.

${ }_{62}$ In the primary legislation, men and women are alternately mentioned first. Although not contributing to increasing equality as such, it is a symbolic gesture confirming that both form equal parts of humanity. Arts 2 and 3 TEU (placing women first), Arts 8, 153, 157 TFEU (mentioning men first). Cf. Arts 10 and 19 TFEU.

${ }_{63}$ Articles 21, 23 and 34 CFR-EU.

${ }^{64}$ Directive 79/7/EEC on the progressive implementation of the principle of equal treatment for men and women in matters of social security, OJ L 6, 10.1.1979.

${ }_{65}$ Exceptions provided in Article 7(1) of the Directive have to be construed narrowly and Member States have to periodically examine matters excluded in order to ascertain, in the light of social developments, whether there is justification for maintaining such exceptions. Strban G. Gender Differences in Social Protection, MISSOC Analysis 2012/2, November 2012, p. 12.

66 CJEU judgment of 22 November 2012 in case No. C-385/11 Elbal Moreno. CJEU judgment of 8 May 2019 in case C-161/18 Villar Láiz.

67 So the Slovenian Constitutional Court in judgment of 20 October 2005 in case No. U-I-69/03. Available at: http://odlocitve.us-rs.si/documents/5c/e5/u-i-69-032.pdf [last viewed December 6, 2019]. 
Hence, not only national legislatures, but also the EU face difficulties in coping with rapidly changing societies and solutions that cause the national social security systems to grow apart. Sensitivity of social security law can be observed in every competence assigned (or not) to the EU. However, it is possible that the existing competencies of the EU are no longer sufficient. Maybe we need a true EU social security system for (mobile) Union citizens, if we want to preserve the characteristics of social security, based on equality and solidarity. Trying to find solutions only for mobile economically active persons might place others, especially non-mobile and non-active Union citizens, in a disadvantaged position.

\section{BIBLIOGRAPHY}

\section{Literature}

1. Becker U. Solidarity, Financing and Personal Coverage. The Japanese Journal of Social Security Policy, No. 1, 2007, p. 1.

2. Carrascosa Bermejo D. Cross-border healthcare in the EU: Interaction between Directive 2011/24/EU and the Regulations on social security coordination, ERA Forum, No. 3, 2014, pp. 359-380.

3. Jorens Y., Van Overmeiren F. General Principles of Coordination in Regulation 883/2004, European Journal of Social Security (EJSS), No. 1-2, 2009, pp. 47-79.

4. Köhler P. A., Zacher H. F. Ein Jahrhundert Sozialversicherung in der Bundesrepublik Deutschland, Frankreich, Großbritannien, Österreich und der Schweiz [Hundred years of social insurance in the Federal Republic of Germany, France, Great Britain, Austria and Switzerland]. Berlin: Duncker \& Humblot, 1981.

5. Pieters D. Social Security: An Introduction to the Basic Principles, $2^{\text {nd }}$ edition, Alphen aan den Rijn: Kluwer Law International, 2006.

6. Strban, G. Gender Differences in Social Protection, MISSOC Analysis 2012/2, November, 2012.

7. Strban G. Patient mobility in the European Union: between social security coordination and free movement of services, ERA Forum, No. 3, 2013, pp. 391-407.

8. Strban G. Family benefits in the EU - is it still possible to coordinate them? Maastricht Journal of European and Comparative Law (MJ), No. 5, 2016, pp. 775-795.

9. Strban G. Constitutional protection of the right to social security in Slovenia. In: Egorov A., Wujczyk M. (eds.), The Right to Social Security in the Constitutions of the World: Broadening the moral and legal space for social justice. ILO Global Study, Vol. 1: Europe. Geneva; ILO, 2016, pp. 243-260.

10. Strban, G. (coord.), Carrascosa Bermejo, D., Schoukens, P., Vukorepa, I.,Social security coordination and non-standard forms of employment and self-employment: Interrelation, challenges and prospects, MoveS Analytical report 2018, not yet published.

11. Strban G. Social rights of migrants in the European Union. In: Davletgildeev R. Sh. (ed.), Regional aspects of integration: European Union and Eurasian space. Moscow: Statut, 2019, pp. 68-98.

12. Verschueren H. Reverse Discrimination: An Unsolvable Problem. In: Minderhoud P., Trimikliniotis N. (eds.), Rethinking the free movement of workers: the European challenges ahead, Nijmegen: Wolf Legal Publishers, 2009, pp. 9-118. 


\section{Legal practice}

1. CJEU judgment of 21 October 1975 in case No. C-24/75 Petroni.

2. CJEU judgment of 15 January 1986 in case No. C-41/84 Pinna.

3. CJEU judgments of 17 February 1993 in joined cases No. C-159/91 and C-160/91 Poucet et Pistre.

4. CJEU judgment of 7 November 2002 in case No. C-333/00 Maaheimo.

5. CJEU judgment of 1 April 2008 in case No. C-212/06 Government of the French Community and the Walloon Government v. The Flemish Government.

6. CJEU judgments of 20 May 2008 in case No. C-352/06 Bosmann.

7. CJEU judgment of 5 March 2009 in case No. C-350/07 Kattner Stahlbau.

8. CJEU judgment of 14 October 2010 in case No. C-345/09 van Delft et al.

9. CJEU judgment of 3 March 2011 in case No. C-437/09 AG2R Prévoyanc.

10. CJEU judgment of 8 March 2011 in case No. C-34/09 Zambrano.

11. CJEU judgment of 24 April 2012 in case No. C-571/10 Kamberaj.

12. CJEU judgment of 12 June 2012 in joined cases No. C-611/10 and C-612/10 Hudziński and Wawrzyniak.

13. CJEU judgment of 22 November 2012 in case No. C-385/11 Elbal Moreno.

14. CJEU judgment of 8 May 2014 in case No. C-347/12 Wiering.

15. CJEU judgment of 23 April 2015 in case No. C-382/13 Franzen et al.

16. CJEU judgment of 8 May 2019 in case No. C-161/18 Villar Láiz.

17. CJEU judgment of 19 September 2019 in joined cases No. C-95/18 and C-96/18 van den Berg and Giesen.

18. Judgment of Slovenian Constitutional Court of 13 December 2007 in case No. U-I-11/07. Available at: http://odlocitve.us-rs.si/documents/b9/45/u-i-11-074.pdf [last viewed December 6, 2019].

19. Judgment of Slovenian Constitutional Court of 20 October 2005 in case No. U-I-69/03. Available at: http://odlocitve.us-rs.si/documents/5c/e5/u-i-69-032.pdf $[$ last viewed December 6, 2019]. 